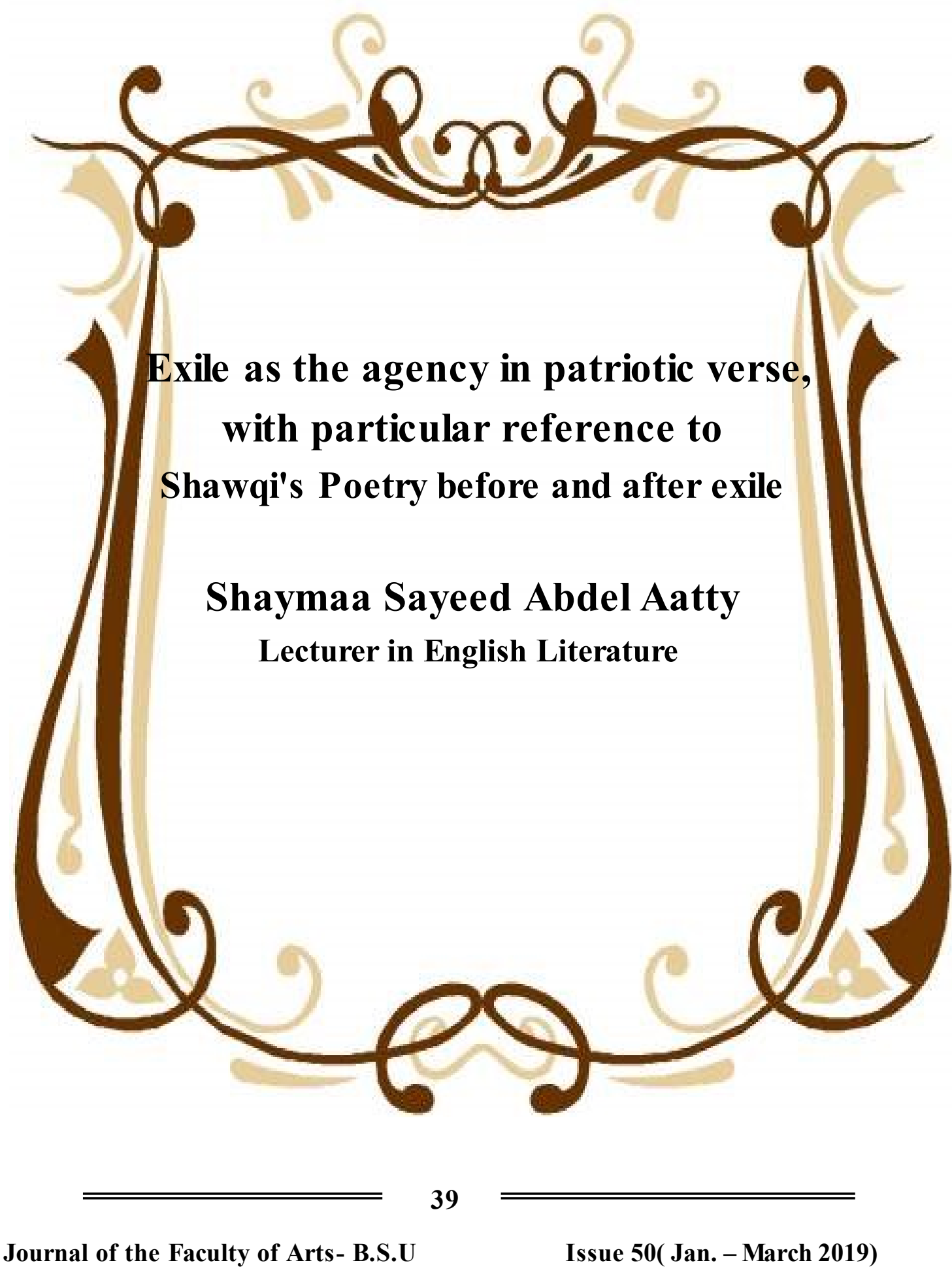




\begin{abstract}
Shawqi wrote national poetry before and after his exile to Spain, but the difference between his poetry in Egypt and his poetry in exile is immense. Before exile, he was accused of being the poet of the princes. He missed no chance to praise them, glorify their deeds, attack their opponents, and recite the incidents they cared about. The critics, thus, claim that he was at that time closer to being an employee in the court, although he had the talent. He was in his ivory tower, with the prince and his entourage sometimes and with his friends at soirees some other times. He was, thus, away from the Egyptian people and their agonies.

For more than twenty years, the period he spent in the court, Shawqi was fettered; he was not free to decide his destination; he felt what his prince wanted him to feel. He was like a songbird whose voice was strangled except when it ex tolled its owner. However, when the Muse released him for a while from the fetters, he composed such poems as "Great Incidents in the Nile Valley" and "The Nile" to document the historical events, to display the various eras and kings and to prove his true princedom of poetry. This true voice was, unfortunately, discontinuous and weak enough to stay in shackles. Because he found in praise the fountain that gave him all he sought, Shawqi was unable to drink, for long, from other fountains such as history or religion.

In exile, Shawqi underwent many hardships that he never knew in Egypt. For the first time, he suffered indigence, ex patriation, loneliness, and sadness over his past blessin gs. Such anguish was important to balance the lux ury, patronage, and familiarity he experienced all his life. Exile, thus, was a turning point in his life. Finally, he took off the mantle of the poet laureate turning to sentimental poetry to describe his yearning for Egypt and its people. His production in exile, however, was not abundant as if he lost the pole to which he used to $d$ irect his poems.

When he returned home from Spain, Shawqi found a new prince, the Egyptian People, to care about. He became the spokesman of the poor, the lawyer of the nation, and the defender of rights. He supported the Arab countries in their struggle for liberty, calling for unity and missing no chance to take the side of an Egyptian or Arabian leader. Finding a new peak - the love of his nation - that he never preoccupied himself to reach, Shawqi offered them his poetry on the altar of national pride and unity.
\end{abstract}

Key Words:

Exile - expatriation - homeland - nationalist

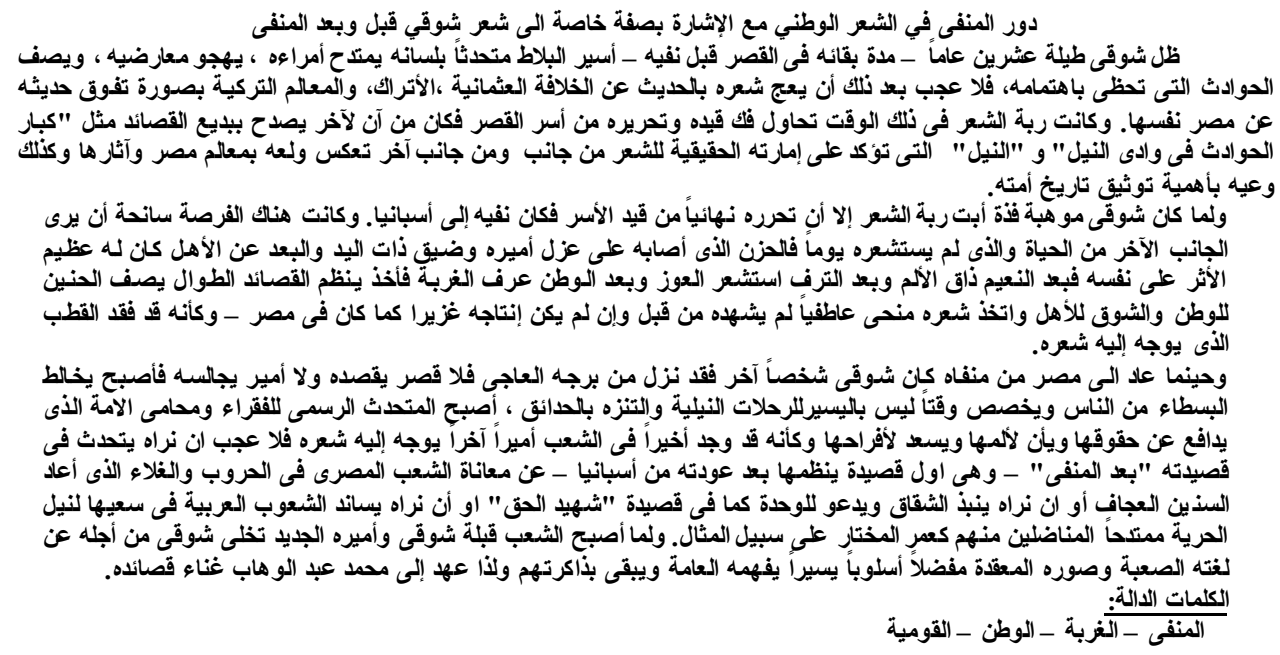


Although it is true that the word "exile" summons vigo rous feelings of solitude and bitterness, men-of-letters have various interpretations of and reactions to being in exile. Edward Said says "I speak of exile not as a privilege, but as an alternative to the mass institutions that dominate modern life. Exile is not, after all, a matter of choice: you are born into it, or it happens to you. But, provided that the exile refuses to sit on the sidelines nursing a wound, there are things to be learned: he or she must cultivate a scrupulous (not indulgent or sulky) subjectivity" (Ayyash 112). It seems that Said chooses to be pragmatic; not only does he adapt to exile but he also exploits it instead of standing on the sidelines to heal his wound. The combination of the two environments, the old and the new, can result in something different. Exile, he claims, does not imply satisfaction, security, or tranquility. On the contrary, it implies breaking the customary order so as to let new realms emerge.

For an exile, habits of life, expression, or activity in the new environment inevitably occur against the memory of these things in another environment. Thus both the new and the old environments are vivid, actual, occurring together contrapuntally.... Exile is never the state of being satisfied, placid, or secure. . . .Exile is life led outside habitual order. It is nomadic, decentered, contrapuntal; but no sooner does one get accustomed to it than its unsettling force erupts anew.

\section{(Ayyash 115)}

Commenting on his interview with Said for Ha'artez Magazine, Ari Shavit observes that Said exceeds being an expatriate who tries to overcome exile, exploit it, or even adapt with it; Said is celebrating being in exile. 
He [Said] takes obvious delight in moving between the various languages and between the cultural levels on which he lives. Between the different identities that skitter within him. As though celebrating his ability to be British and American and Arab all at the same time. Both a refugee and an aristocrat, both a subversive and a conservative, both a literateur and a propagandist, both European and Mediterranean.

\section{(Ayyash 112)}

It is choice that makes one differentiate between being an exile and an expatriate. Bereft of one's right to stay in one's homeland, an exile feels marginality and worthlessness "Once banished, the exile lives an anomalous and miserable life, with the stigma of being outsider" (Said 144). The expatriate, on the other hand, does not experience such strong feelings of bitterness and misery as the exile although they share the same solitude, choosing voluntarily to live in another country for some reasons. An expatriate is neither obliged nor marginalized. "Hemingway and Fitzgerald were not forced to live in France" (144), Gibran Khalil Gibran and Mikhail Naima got the American nationality after their departure for the United States of America and were prominent figures in the literature of exile together with Elia Abou Madi and other figures.

Similarly, James Joyce chose willingly to leave for France. He thought that being in exile can "give force to his artistic vocation" (Said 145), it was the same idea stressed by Gertrude Stein who chose France to be her home for the rest of her life. Stein affirms that "writers needed two countries because their creativity depended on transplantation" (Zac- 
caria 120). Writers need to change the state of stability or perhaps the stagnation they have in their homelands "the tension between home and exile, familiarity and strangeness can be positive, productive: only the exiled individual can gain enough distance from society to be truly creative, to envision alternatives" (Zaccaria 121). Exile, Joyce claims, is to break the familiarity, the thing that solidifies the bond with the homeland "Joycepicked a quarrel with Ireland and kept it alive so as to sustain the strict opposition to what was familiar........whenever his relations with his native land were in danger of improving [Joyce] was to find a new incident to solidify his intransigence and to reaffirm the rightness of his voluntary absence" (Said 145).

\section{The Paradox of Exile:}

In his book "reflections on exile" Edward Said deals with the close association between exile and nationalism. He defines nationalism as "an assertion of belonging in and to a place, a people, a heritage. It affirms the home created by a community of language, culture, and customs" (Said 139). It seems that exile with such implications as yearning and solitude fuels this sense of belonging "indeed, the interplay between nationalism and exile is like Hegel's dialectic of servant and master, opposites informing and constituting each other. All nationalisms in their early stages develop from a condition of estrangement" (Said 140). Expatriates in the new countries try to compensate what they left behind in their homelands; they search for new people, new history, and new bonds with the new land. Some of them can overcome their crisis of estrangement, another group can reach a higher stage than the first one; they can adapt with the new conditions exploiting their privileges. A third group, and perhaps 
the most distressed, can not belong to a new land. They only belong to their native land, their roots, and their history and so their national feelings deepen "exiles are cut off from their roots, their land, their past. They generally do not have armies or states, although they are often in search of them. Exiles feel, therefore, an urgent need to reconstitute their broken lives, usually by choosing to see themselves as part of a triumphant ideology or a resto red people"(Said 140-41). This division of the expatriates into three categories may match a similar division presented by Hugo of St. Victor, a twelfth century philosopher and mystical writer

the man who finds his homeland sweet is a tender beginner, he to whom every soil is as his native one is already strong; but he is perfect to whom the entire world is as a foreign land. The tender soul has fixed his love on one spot in the world; the strong man has extended his love to all places; the perfect man has extinguished his.

(qtd in Said 147).

Perfection is the share of the man who extends his love to the whole world taking it as an all-encompassing home. This idea is also stressed by the philosopher George Santyana who says "what is life but a form of motion and a journey through a foreign world" (Soroka 22).

A case in point, raising possibly other questions abo ut exile, is that of Ahmed Shawqi, the illustrious Egyptian poet, who eventually was regarded as "the prince of poets". Shawqi wrote nationalistic (i.e. patriotic) poetry before and after his exile to Spain. To what extent does exile affect Shawqi? To what catego ry of expatriates does Shawqi belong? are among the questions this study seeks to answer - apart from per- 
haps other questions.

Shawqi's Exile:

Although Ahmed Shawqi is the only poet in the Arab literary tradition who has been granted the title "the prince of poets", he never rode out the bitter criticism of the AlDiwan school. The main thrust of the attack on Shawqi was that he was too objective for the romantic propensities of AlDiwan school (Abbas Al-Aqqad, Abdel Rahman Shoukry, and Ibraheem Abdel Kader Al-Maziny). Al-Aqqad in particular denied any real poetic quality in Shawqi, as he believed that the poet is he who feels. He believed that Shawqi is one of "the lame who creep to fame" (Al-Aqqad, Al Addab w Al Naqd: 1 517).

Shawqi, according to some of his cotemporaries, was not the "prince of poets" but rather "the poet of princes". He never missed a chance to praise the Khedive, who showered him with gifts. What other men-of-letters see as a demerit was to Shawqi a reason to be proud.

The poet of the prince; a title that is so lofty

(Shawqi, Al Shawqiat 2 p 9)

In his book "Hafez and Shawqi ", Taha Hussein says, "Shawqi goes on in this way as an employee in the court, the poet of the prince, who praises him whenever called for or even without a call. He is creative in such praise, mastering its prelude, the love poetry and description, although not equally mastering praise itself" (131). Hussein goes on to say that Shawqi claims that he hates the panegyric form, and wishes that poets would abandon the genre, although he him- 
self is willing to be an intimate companion of the prince, and keen to be his poet, envying Al Moutanabi for being close to Abi Feras Al Hamadani. This is perhaps, as Hussein claims, the reason "that weakens Shawqi's wing making him seem more like poultry than a bird flying through the air" (121). In his book "Al Diwan" Al Aqqad gives Shawqi a loftier title than that of Hussein, who describes him as a mere "employee in the court". Al Aqqad describes him as "a literary deputy in the court" (520). According to Al Aqqad, Shawqi only sought fame, and his affiliation with the court was a means to this end, through those journalists who devoted pages to praising Shawqi and his work in their newspapers, while criticizing other poets.

Shawqi, on the other hand, never saw a difference between loving Egypt and praising its ruler, defending him against the occupation. In the introduction of his poetic play "Magnoon Laila" Shawqi praises King Farouk, describing him as the loftiest monarch in the Arab world. Farouk and his great father are described as soaring eagles and high meteors that can defend the homeland and the River Nile, from the headwaters to the estuary. They seem like a catalogue about ethics and decency. Shawqi, moreover signed his preface to Nahj Al Burda as "your slave" addressing the Khedive Abbas Helmy II.

His support for the royal court and the Khedive Abbas Helmy II was unprecedented. He stood by him in his conflict with the British occupation, praising his advocates and damning his opponents. Among those who were attacked by Shawqi for praising the occupation and opposing the khedive is Ryad Pasha, the prime principal. 
You flooded those folk with praise

And with blessings they flooded you in return

You gave your sermon and become a disaster, not an orator

Added to our great woes,

You extolled the occupation

Whereas your wound is still bleeding

(Shawqi, Al Shawqiat 1 p 209)

In his book Shawqi: the poet of the modern age Shawqi Daif affirms that Ahmed Shawqi, at that time, stood apart from the Egyptian people; he was in his ivory tower at the side of the court. He was like "a vane which goes wherever its owner goes" (17). Even when he attacked Ryad Pasha or Lord Cromer shortly afterwards, Shawqi was not actually stimulated by pure patriotic feeling, but was driven by his affinity to the court and his keenness to protect the spoils he had gained "Shawqi did not get angry for his homeland or for his people; he got angry for his prince. All he cared for at the time were the privileges he gained and the palace where he lived, the palace of Mohamed Ali's family with Abbas at the throne"(18). To verify his claim, that Shawqi's loyalty was to his interests, Daif presents the Denshway Incident as a proof. In brutal trials, many of the villagers were hung, others were jailed, and a third group was tortured. Egypt grieved and sorrow filled the hearts of its people, but Shawqi remained silent. Opposing the Khedive was a stronger impulse to write than killing Egyptians. Shawqi "was not of the Egyptian people; he grew up in the court, and trailed after 
his prince Abbas, feeling what he feels, having no independent sensation; and so he revolts when his prince is slightly insulted, yet holds his tongue when his people are slapped in the face" (20). Daif goes on to confirm Shawqi's feigning passions and affectation. It was only with the aim of appeasing his readers and saving face that Shawqi wrote some verses on the anniversary of Denshway.

Shawqi led a luxurious life that left its impact upon his poetry. From an early age, gold was freely disbursed to him; he grew up under the auspices of the Khedive himself. As a lad, he was an employee in the court and one of the prince's mentors. He never tasted indigence; on the contrary, he was showered with gifts from the prince, who sent him to study in France. From France to England, Algeria, Switzerland, and Belgium Shawqi spent his life traveling, studying, enjoying himself, and reciting poetry. In Egypt, he selected a palatial mansion near the royal palace to be close to his prince. He was never in touch with the low or even the middle classes; he was either with the prince and his entourage in the court or with his friends at soirees entertaining and drinking wine. This is why Shawqi was far from the Egyptian People and their way of life. While his nation was suffering from occupation, struggling to attain its liberty, Shawqi was writing about wine

Ramadan has gone, oh barman bring me wine

We yearn for each other

(Shawqi, Al Shawqiat 2 p 77)

It seems, as Mohamed Hussein Hekal claims, that Shawqi has a dual personality; the sybaritic self-indulgent person who 
had all the pleasure he sought and the pious god-fearing one. This duality, however, was not to devalue the talent of Shawqi or his patriotism. In both cases he was a skilful poet who sanctified Egypt in his poetry.

Shawqi's opponents claim that he attacked Orabi for his revolution against the perversity of the court and mourned Moustafa Kamel a year after his death when he became sure that the khedive would not be angry because of such an elegy. He was a hypocrite, doing everything he could to appease the khedive, and at the same time he tried to placate the Egyptian people. Thus, in his elegy about Kamel, he enumerates his traits as a friend, not as a great patriot, ignoring his endeavor to attain liberty, handling instead the philosophy of life and death. In his book "Al Diwan", Al Aqqad refuses to call this elegy a poem; it ought to be called "sixty four lines to tell about everything or nothing" (Al Aqqad 591). While Shawqi sees praising the rulers as a national duty on the pretext that the court symbolizes Egypt and there is no time for disputes and conflicts in order to overcome the occupation, the critics unmasked the reasons behind his affinity for the court: the first was the care the court provided him with; the second was the common belief at that time that the Ottoman Caliphate was an Islamic Caliphate and so, all should defend it. Shawqi, like many poets of his age, sees in the caliph the sanctuary; he asks him for protection and victory over the enemies.

Oh! Our leader, we beg you to achieve victory for Egypt, as the sword supports the sword

because Egypt -you know love best- has, in your protec50 
tion, its refuge.

(Shawqi, Al Shawqiat 1 p 243)

Shawqi Daif claims that Ahmed Shawqi was not free to decide his destiny; he was directed or perhaps forced by his prince Abbas who, in order to appease the Caliph and gain his support, directed Shawqi towards the Caliphate, and Shawqi in his turn missed no chance for sending his hymns and poems of praise on behalf of the Caliph, glorifying his deeds and enumerating his favors. The Turkish wars with the Persians, in Balkan, whether in victory or in defeat occupy much of his poetry. Abbas was loyal to Turkey and visited it in summer; so did Shawqi. The Ottoman Empire, the Sultan, the Turks, Turkish events and sites have a broader scope in his poetry than those of Egypt. No wonder, then, to find his accurate depiction of such places as Picfor and Jekso. Inaugurating one of his poems, Shawqi, addressing Jekso, says

Oh Jekso! My greetings to you

As nothing can amuse the soul except you

(Shawqi, Al Shawqiat

2 p 52)

For more than twenty years, the period he spent in the court, Shawqi was captive; he was like a songbird whose voice was stifled except when it flattered its owner. However, when the Muse released him for a while from captivity, he penned such poems as "the great incidents in the Nile Valley" to prove his true princedom of poetry. This true voice was, unfortunately, intermittent and weak enough to stay in captivity. The poet was much pleased with such a bond; he found in praise the 
fountain that gave him all the privileges he sought, returning to it quickly if he was obliged to drink from other fountains as history or religion.

The fair-minded critics during and after Shawqi's life tried to exonerate him of the accusations his opponents stuck to, affirming that the critics who attacked Shawqi were seeking fame by such bitter criticism; they needed a generation to outgrow it, and this, as known at that time, was Taha Hussein's reply when he was asked about the reason for his attack on Shawqi. The Jordanian critic, Gameel Aloush, declares that Al Aqqad was unjust in criticizing the poetry of Shawqi as he attacked Shawqi as a person, not only as a poet; he doubted his patriotism because of his Turkish origin. He called Shawqi "the poet of the court" who dedicated his poetry "to serve his master" (Abdel Lattif 48). Many poets such as Ali Al Garem and Azeez Abbaza, Aloush claims, extensively praised the Royal Family without being lacerated by Al Aqqad's bitter criticism. Moreover, Al Aqqad himself, in a less powerful and sober style than that of Shawqi, praised the kings Fouad $I$ and Farouk $I$ in various occasions encircling the royal family with an aura of holiness. Shawqi, on the other hand, phrases his loyalty to the court in a lofty cultured manner that shows his sublimation and trustworthiness, saying:

Should I betray Ismael's sons although I was born under Ismael's patronage?

(Shawqi, Al Shawqiat 1 p 216)

In his prose work "Aswak Al- Zahab" or "the Markets of Gold" Shawqi, expressing his deep love of Egypt, says "the home is the birthplace where the wishes of the heart are 
compiled, where the fathers and the grandfathers are buried. It is the profane life and the threshold of the Other World. The heir that is inherited and transferred from a tiller to another, and so on until the moon eclipses when the earth stops turning" (Shawqi 10). He goes on to say that the homeland is the first breath that entered his lungs, the first place where his small palms to uched dust during play, the place where he enjoyed his youth, the planet of excellence, the way to glory, and so on.

Shawqi adores Egypt and his poetry reveals much of his affections for it. When he talks about Egypt he is not a poet but rather a sincere lover and a custodian. He never misses a chance to advise its people, stir their zeal, and tackle their agonies. Realizing that unity is the only means of independence and triumph over the occupiers, Shawqi urges his nation to cast aside their disputes. There is no difference, he affirms, between Muslims and Christians but the colonizers found such matters to fuel the strife among the people of one nation. To rouse in his people the patriotic feelings with no distinction, Shawqi, in his poem "Ya Shabab Al-Diar" (O Youth of the Homeland), says

We, Muslims and Christians, are one nation down the generations

The Nile is our father, and then came our grandfather Adam.

(Shawqi, Al Shawqiat 1 p189)

He goes on to say that we were all created by Allah, and for centuries we all tasted the bitterness of occupation, restrained with no distinction in its chains. Jesus was proud of the 
Christians and similarly Taha, one of the names of the prophet Mohammed, was proud of the Muslim nation. Youth are lion cubs who should defend their den, Egypt, without conflicts because religions are paths to God, and on their path to God some people carry a cross while others carry a crescent.

In spite of the great effort the opponents of Shawqi exerted to distort his image, derogate his patriotism, and arouse suspicions concerning his intentions and incentives, Shawqi's unrivalled fidelity proved to be to Egypt first and foremost. Shawqi, who was the poet of the court and who was always accused of hypocrisy and chasing after fame, attacked the American president Theodore Roosevelt, the guest of the Khedive, Ahmed Fouaad, breaking the protocol of the court and defying the government that kept silent when the president offended Egypt and attacked Islam in his speech in the Egyptian University. In one of his poems, Shawqi did not only give the president an unforgettable lesson in respecting the Egyptian civilization but he also showed how much pride he had as he belonged to this great nation. He seized the opportunity of the president's visit to Philae Temple, which was about to drown in the Nile, and recited his poem telling the visitor to take off his shoes in order not to desecrate such a sacred place, lower his gaze in reverence, and humble himself before this grandeur. He goes on to describe the kinds of art and creation one can find in such place. The statues are ancient and are about to sink in the Nile but one becomes infatuated when he sees the carvings that seem recent as if the sculptor has just finished his work. The luster of the varnish also seems fresh as if time has not passed. The graphs and writings on these statues look as accurate and attractive as the eyelashes of the gazelle. In a vibrant image, the statues 
are about to move as if life will be breathed into their bodies by the Almighty. Over this deep-rootedness that is about to sink, Shawqi sheds his tears saying

I am celebrating the history of Egypt

He who preserves the glory of his people is a guardian of honor

(Shawqi, Al Shawqiat 2 p58)

In a similar situation, Shawqi attacked Lord Cromer because the latter assaulted Egypt and insulted its people who, in his opinion, were ungrateful to the English people denying their favor and the effort they exerted to civilize Egypt. To express his deep rejection of the occupiers, Shawqi likened Cromer to a serious disease and said that the day of his departure was the day of the nation's recovery.

Shawqi was fascinated by the history of Egypt, its monuments, and its civilization. His poetry is thus a record of this history the occupiers sought to eradicate. He reminds people that they have a great civilization to defend, stirring their enthusiasm to ablate despair. His long poems "It is the Nile", "Farewell Cromer" and " Great Incidents in the Nile Valley" are the best examples of such poems that document events and depict the greatness of the nation. In "Great Incidents in the Nile Valley", about three hundred lines, Shawqi lists the aspects of Egypt's greatness and glory since the dawn of history. In this poem, which he recited when he was a delegate of the Egyptian government in Geneva International Conference 1894, Shawqi displays the different eras of Egypt's history. He begins with the glorious era when Egypt was a beacon dominating the world; the ships in countless 
number were running in the seas as if they were a spacious desert that was full of hills. Because they were so fast, the seas seemed too tight to carry such giant ships. The sails of these vessels seemed as if they were guiding the water. Similarly, their excellence, on land, was peerless; they built towering pyramids and tall temples that could reach the sky. Their deeds were so great as to scare the jinn and infuriate the enviers. Even in its eras of weakness Egypt did not fall; it kept struggling against those gloating occupiers who, urged by endless cupidity, tried to defile its land. Egypt at that time was like a beast that succumbed to its hunter for a while to flee from captivity. Thanks to its people who gave their lives to protect their homeland, Egypt soon regained its exalted position.

Shawqi's admiration for such kings as Ramses and Alexander the Great was immense. During their eras Egypt was flourishing; it was a place that others moved to because it teemed with all kinds of sciences and arts. While other nations lived in darkness, Egypt had such great poets as Bentahour and such great armies that could not be subjugated.

In reverence, solemnity, and sacredness Shawqi always describes Egyptian monuments and landmarks. The pyramids and the River Nile in particular have the lion's share of Shawqi's respect and concern. In his poem "at the foot of the Pyramids" which was recited to celebrate the Syrian poet Ameen Afanddi Al Rehany when he came to visit Egypt, Shawqi asks the guest to stand solemnly to talk to these majestic pyramids composing poetry about these three miracles. To praise the poet, Shawqi likens him to the exalted sacred temples abounding with worshippers; and to praise his work, Shawqi describes it as eternal as this divine place, asking him 
to kiss the stones in this place, to glorify the hands that carved these perennial statues, and to draw notability from Egypt as it is the cradle of knowledge and excellence.

In the same tone of reverence and sacredness, Shawqi idolizes the River Nile. "How long has this Nile been running?" the poet asks. Did it descend from the Heaven? Was it formed because of a cloud or an overwhelming flood? How can it weave these green blooming banks that never know barrenness? These rhetorical questions with which Shawqi inaugurates his poem "O Nile" are intended to entrench the fact that this Nile is so glorious and munificent. Over the centuries the Nile has been flowing, feeding people and quenching their thirst generously without stinting.

You pour water as if it is gold, deluge the land and so it is enlivened

All minds appreciate you, the illiterate and erudite as well

\section{(Shawqi, Al Shawqiat 2 p66)}

Throughout ages, people have adored the Nile, praising its bounty, revering it as if it were a deity. In an unprecedented hyperbolic image, Shawqi says that if a creature could be worshipped, it would be the Nile. The valley has been showered with blessings because of the Nile. Nothing less than the might of God can bring death to His creatures, except that river. It is the fountain of sagacity and wisdom; it was the sanctuary where the prophets Jesus, Joseph, and Moses went to in their hard times. Because it is stupendous and notable, people from remote places go on pilgrimages to it and passing crowds stop and stare at it. At its banks one smells the fra- 
grant musk as if there is ceaseless flaming incense. Even the great queens like Balqees borrow or perhaps steal of its beauty but unlike those charming queens whose prettiness fades, the Nile has enduring beauty. No other nation has such a great Nile; it is running in Egypt, not in Persia, Baghdad, or Damascus. People who sanctify the Nile never scant their lives to show how glorified it is. Reverently, in annual majestic ceremonies, the Egyptian people used to sacrifice a virgin girl for the sake of the Nile. The girl who is thrown in the Nile, in spite of the death she meets, seems as if she is a bride rejoicing and yearning for her groom; so she is envied by the other maidens who also seek glory.

The Nile is the cradle of civilization, around its banks one finds wise sayings carved on the rocks and written on Papyrus. It is the minaret of sciences and the origin of monotheism: A lofty place ennobled by the lofty constellation that trod its banks. In its water the bier of Moses was floating, the beauty of Joseph was blazing and the tears of repentance from Joseph's brothers fell into it. The plants grew with the blessing of Mary's prayer and the steps of Christ at its surface were blooming. The Nile also witnessed the Islamic conquest at the hands of Amr Ibn Ala'ss and the other companions of the Prophet Mohammed who came with justice and righteousness. No wonder then to find that harmony in such land that renounces division; the rabbi, the priest, and the Imam all perform their prayers freely and peacefully. In an expressive image, Shawqi depicts The Nile Valley as the banquet of Hatem Al Ta'ai, the person who is said to be the most generous in all Arab culture. The host, after feeding people and quenching their thirst, bids them farewell and opens the door to the other groups who knock to welcome them too. 
During his stay in Spain, after being exiled in 1915, Shawqi wrote many poems that reflect his irresistible homesickness. In his long poem "Exile and Nostalgia" Shawqi is remembering and longing for his beloved home, Egypt, and the happy times he spent there when he was youngster. He says that he never forgets his country although time and the successive days and nights cause oblivion. So he asks his imaginary companions to summon his far delightful memories in Egypt that never leave his mind. These happy memories of youth passed away promptly like wind that blew and went rapidly with pleasure. In his answer to the questions "has the heart forgotten Egypt?" and "has time cured his heart's ache?" Shawqi admits that his heart only became more delicate, although time hardens hearts, making them cruel. Out of overpowering hankering and nostalgia, this heart is watching the ships in their movement and moorage in order to go back and reunite with the beloved country. Addressing these ships, Shawqi asks the reason for the sea's stinginess with him in spite of its generosity with others. It is this sea that hinders the encounter with his beloved. Being deprived of his homeland, his people, and his memories, Shawqi likens himself to a bird that is forbidden to dwell its tree which is nested by all other species. Every home is a right for its people except in brutal unfair ideologies, like that of the occupiers. Imploring the ship to carry him to the homeland, the poet promises to carry out its requirements making his breath its fuel, his heart its sail, and his tears of longing its sea. He asks it to make the lighthouse of Alexandria its destination and Al Thaghr, a port between Al Raml and Max, its stream. His love for Egypt seizes his heart and soul; if he was granted eternity, he would be busy thinking over Egypt even in Heav- 
en.

Day and night make one forget

So, tell me about my early days

And describe that period of my youth

that was shaped by imagination

Blew like the playful Saba (wind) and gone

Like a sweet drowse and a quick pleasure

And thou shalt ask Egypt; Has the heart forgotten Her?

Or has Time cured its wound?

Whenever nights pass, it gets delicate

Though nights make the heart cruel

Turning mad if the ships sounded their foghorns

At the early night or howled after the bell

Like a priest in the chest, well-aware of the ships

When they move, the heart saw them off with beating

$O$, daughter of the sea, Your father is not miserly

Why then is he fond of prevention and imprisonment?

Is it forbidden for its birds to sing

60 
While it is allowed to all other species?

Every home is a right for its people

Except in bad and mean ideology

My breath is fuel, my heart is a sail

With them you sail in tears and come to shore

And make the Fanar (Lighthouse of Alexandria) your destination

And the Thaghr between Raml and Max your stream

O, my country, if I were to be kept busy by eternity

My soul would long for it in heaven

Allah is a witness; my country is never away from my eyes

And it is never far from my heart.

(Shawqi, Al Shawqiat 2 p45-46)

All day and night, Egypt never leaves the poet's mind. He describes its places as if he is seeing them. He is remembering Al Jazerra with its groves that are lodged in by the singing birds. It looks like the beautiful queen Balqees who is beautified and well-dressed to wed the River Nile which is also likened to Al Kawthar, the river in Paradise. He can also see Al Giza that looks afflicted and sad over the absence of Ramsses. He never forgets the pyramids and the doom it brought to the tyrants. The great eternal Sphinx with its animal shape and human head is also embodied in his imagina- 
tion. Proudly, Shawqi talks about the greatness and superiority of Egypt in such different fields as astronomy and the battlefield. He mentions how it defeated such great armies as the Roman and the Persian, and how it ruled the world for centuries.

The pain that fused the poet's heart because of expatriation, loneliness, lack of money, the gains he lost, and the khedive who was dethroned was a must to release his talent, to make him feel the agony of others, and to set him free from the cage of the prince. Shawqi who grew up in the palace experiencing all kinds of luxury and pleasure is now suffering and consequently his humanity comes to its fullest. His psyche as a poet can feel the both sides of life "pleasure and pain, blessing and deprivation" (Daif 33).

"Andalusia" is another poem that reflects Shawqi's agony in exile and his inescapable yearning for the homeland. He inaugurates the poem by addressing a lamenting bird, a symbol of Al Mootamed Ibn Abbad, one of Andalusia poets who were also banished from their country. Shawqi says that both he and that bewailing bird have the same disasters; both have been exiled and have sweeping eagerness for their valleys, the Nile Valley and the Seville Valley. Both are victimized by the same tyrant; the hand that gashed the wing of the bird was the same hand that cut out the poet's bowels. Departure is fated upon both of them; now they are living in places that are not their homelands with people other than their kinsmen. Of different ethnicities, both of them have the same anguish and longing. Their bodies, in spite of the ills they have, can be cured unlike their souls whose wounds are incurable. Although they are now residing in a beautiful green 
land, they still feel foreignness.

With an overwhelming sense of loss and deprivation, Shawqi yearns for Egypt that is likened to a spring filled with Camphor. It is the place where he enjoyed his youth and achieved his wishes. It is the valley of beauty; Azure and Aquamarine extend along the Nile shore together with the green fruitful orchards. Reacting to the poet's feelings, in a pathetic fallacy, the nature also becomes sad; the lightning sheds its tears, the rain, exactly like the poet who dyes the land with his bloody tears. His beloved country gives its all to its people who in return find that their lives are the least thing to offer. He adores Egypt and finds himself jealous of himself over this beloved. He ennobles his love for his country keeping it away from enviers. Yearning for reunion, the poet resorts to patience to alleviate his pain but in vain; it can not help. It is the first time he is overcome by his tears; his fortitude fails. He is now weak although he is in a fortress. In the darkness of the night he is bemoaning but he hides his agony in the daytime to flee from people's gloating.

Sorrowfully, the poet laments the past blessings and the happiness he left behind in his homeland. He remembers the greenery of the groves, the sun that struts as if it is a pretty queen, the Nile that comes to bring prosperity and felicity. The Eon has never seen such people as his nation. They are generous and committed. In battlefields, they are valorous militants and noble knights. They are like rubies that become more precious with the glow of fire. The sun has never found a perfect throne except in this land, the cradle of civilizations, upon which the eternal great pyramids appear like a bulwark 
that never perishes with the subsequent ages.

In Exile, Shawqi seized the opportunity and broadened his knowledge of Andalusia, its civilization, history, and renaissance. Furthermore, he delved into Andalusian literature, appreciated its poetry and admired its writers. Shawqi, who was much closer to the poetry of Al Moutanabbi, as one of the most prominent poets of praise among ancestors, is now reading Ibn Zaidon. One can notice a leap in Shawqi's poetry as he turned to sentimental poetry, the trend that he never followed before exile. Greatly affected by Ibn Zaidon in his no stalgia for Waladah, Shawqi composed his "Andalusia" to release some of his distress in exile and to prove that he took off the mantle of the poet of the court.

Although different, his poetic output in Andalusia was limited, as if he lost the destination to which he should direct his poetry. However, he found his destination again when he returned home taking, instead of his old prince Abbass, "a new prince that is his people" (Daif 40).

The calamity of being exiled and the agony he felt in exile made Shawqi more sensitive to the tribulations of his people. Descending from his ivory tower, Shawqi now becomes the spokesman of the poor and the lawyer of his nation. The person who was born with a silver spoon in his mouth is now talking about the high prices and the hunger the Egyptians face. In his poem "After Exile", the first poem he wrote immediately after retuning home from Spain, he asks the youth to entreat God to alleviate the torture from which his country suffers. After being crushed in wars, Egypt has many economic ordeals. Its people are starving; greedy tradesmen monopolize goods leaving the crumbs for the people who, for food and clothing, face insurmountable hardships. 
From Basus War to high cost of living that is about to repeat the seven lean years

But is there another Joseph to act prudently, doing the right thing.

Oh God! Your slaves are hungry in Egypt. Do they have a Nile or a mirage?

\section{(Shawqi, Al Shawqiat 1 p67)}

Shawqi returned home at the time of popular uprisings and struggles against the occupiers. He took their side defending their right of freedom and proving his true patriotism but he was much hurt by the strife of the different parties, inviting them to reunite.

Agony, astonishment, and blame are all united in "A Martyr to Truth"; the poem Shawqi wrote seventeen years after the death of Moustafa Kamel to mourn him. Shawqi inaugurates his poem with blaming the different factions of the national movement affirming that there is no reason for discord which leads only to aversion and enmity. The only winner amid such flames of repugnance is the occupier; he lives in peace whereas the nation suffers an endless war of dissension. With great grief, he goes on to ask the seeming nationalists about their principles and their slogan to die for the sake of the homeland accusing them of following their whims and inclinations, not the mind or the conscience, the thing that led them to perdition. Their spears of strife first injured Egypt, so the wounds and sorrows are countless. Those discrepant squads are now like cancerous cells; they turn in vicious circles of hatred with no hope of healing. For more than half a century of occupation, the parties fought for nothing; they 
were neither reformers nor good-tempered. They wasted their history; after being leaders of humanity and makers of civilization, they fell behind. In a meaningful image, Shawqi expresses the state of backwardness that afflicts the nation because of conflict, portraying the Egyptian politicians as strong as lions but then they became evasive and irresponsible as ostriches, doing nothing except silence sometimes and making speeches some other times.

It seems that Shawqi misses such valiant sincere figures as Moustafa Kamel. In such atmosphere of strife and rivalry, Shawqi yearns for Kamel, the martyr to the truth, the person who sacrificed his life for the sake of the homeland. Because of his peerless loyalty and nonesuch valour, Kamel seems a stranger amid those feigning nationalists. When Kamel became ill, the soul of the homeland became ill too. In his funeral, people rallied to cover the earth to bid him farewell. Shawqi lists Kamel's traits that combined to form a great patriot; he was the defender of rights whose chivalry and courage cannot be denied by anyone. Unlike the capricious, whimsical people who claim nationalism, Kamel advocated their rights overtly with no fear. They stood silent, whereas his speeches were shaking the thrones of tyranny. His voice was as strong as the trumpet that resurrects the dead people on Judgment. His speeches were a bitter pill to swallow for the enemies; they were like the roar of the lions. Kamel, according to Shawqi, was the best, last nectar of nationalism; he planted its vine seeds and so he gained the best wine. Patriotism before Kamel was something like a superstition or a dream. It was he who carried on his shoulders the issue of the independence of the homeland, shaking the whole world with his sonorous speeches when he was a boy and then when he became a young man.

Shawqi never sees the geographical borders that sepa- 
rate the Arab countries. The Arab people are tied firmly with strong bonds and every one in any of the Arab countries belongs to his homeland, the birthplace where he was born and grew up and belongs at the same time to a wider homeland, the Arab nation. He says

The East is but a family or a tribe

All are afflicted at every sorrow

(qtd in Daif

157)

No wonder then to find Shawqi mourning Omar Al Moukhtar, that Libyan combatant who was hung at the hands of the Italian occupiers. Addressing Al Moukhtar, Shawqi says:

They put your ruins in the sand as a flag that mobilizes the valley day and night

Woe unto them; they instated a minaret of blood that inspires the new generation to hate the occupiers.

(qtd in Daif

157)

He upheld the Arabian Peoples in their struggle to attain liberty, recording their revolutions in his poetry, missing no chance to celebrate an Egyptian or an Arabian leader.

Shawqi became closer to the Egyptian people and more susceptible to their suffering. His past aristocratic proclivity was diminished. He was released from the captivity of the court. He found his lost self among the ordinary people. He left his stately house, or Karmat Ibn Hanei as he called, taking a new house in Al Giza. He became busy roaming and going out on picnics, visiting the Nile, the Pyramids, and the other monuments, that were deeply loved and hallowed in his poetry. In one of his visits, he composed his poem "The Sphinx". In his poem that is entitled "the Sphinx", Shawqi talks about the magnitude of this statue and its skillful carver. It baffled people throughout the ages because of its 
mien.

Oh Sphinx! You have been living for long time reaching the utmost age

As if you are the twin of the Eon although both of you are still young

You rode the sands wrapping the day and night up

Traveling throughout centuries, so when will you shake off the journey dust

Do you have a covenant with the mountains to pass away together?

(Shawqi, Al Shawqiat 1 p132)

It is the imperishable statue that perplexed both Bedouins and townsmen because of its odd appearance having a human face and an animal body. It symbolizes the strength of the wild animals and the insight of human minds. It is immemorial; it is the guardian of land, the repository of people's secrets, and the witness of all the incidents that happened all over years. It witnessed the tyranny of the Caesars and the fairness of Alexander the Great. It saw the different deities as Isis and Apis; and then with the coming of the Abrahamaic religions it saw Moses, Jesus, and Mohammed. It bids farewell to the leaving generations, receiving the coming ones. It witnessed the aberrance of the kings and the sanctity of Omar, the second Caliph in Islam.

Shawqi who was chained to his prince, the Khedive, found a new presumed prince, his nation. The peak that he attained as the poet laureate preoccupied him so much that he could not see another peak, his nation's love and esteem. To attain the new peak and to reach the heart of the new prince, Shawqi relinquished his eloquent standard style, preferring instead a simpler style and indelible diction, selecting one of the most eminent singers at that time, Mohammed Abdel Wahabb, to sing his poems

68 
Critics say that Shawqi lent a helping hand to Wahab. However, it is also true that Wahab lent one to Shawqi, helping him transcend the literary saloons and narrow forums and placing him on records widespread across the Arab world and later on the radio. This allowed his poetry to be heard by the general population. An emotional and creative link existed between Shawqi and music and singing. He was a poet whose poems reflected the language of music, to the extent that it was said that he was born to be a musician but became a poet. (Al Rifai , 84)

Works Cited:

AL-Rifai, Nada Yoysuf. Lyrics in the Poetry of Ahmad Shawqi. PAAET, Kuwait: College of Basic Education, (2015).

Ayyash, Mark Muhannad. Edward Said: Writing in Exile. Comparative Studies of South Asia, Africa and the Middle East. Duke University Press. Vol. 30, No. 1, 2010 PP.101-18

Said, Edward. Reflections on Exile. Cambridge: Harvard University Press, 2002.

Soroka, Maykola. Faces of displacement: the writings of Volodymyr Vynnychenko. London: McGill Queen's University Press, 2012.

Zaccaria, Paola. The fall of the dream of a national/ monological discourse: in the polylinguistic/logical texts of exile literature. (1995).

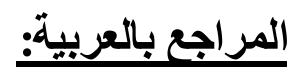

- شوقى، أحمد. الأعمال الثعرية الكاملة(المجلد الأول). بيروت: دار العودة، 1988

- شوقى، أحمد. مجنون ليلى ـ القاهرة: مطبعة مصر، 1916. 
- ضيف، شـوقى. شوقى شـاعر العصر الحديث. القاهرة: الهيئة المصرية العامة للكتاب، 2010. - حسين، طله. حسافظ وشـوقى ـ القاهرة:مؤسسـة هنداوى للتعليم والثقافة، 2012 - العقاد، عباس محمود. الأدب والنقد 1(الطبعة الثانية) ـ القاهرة: دار الكتاب

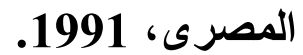
- العقـاد، عبـاس محمـود. الـديوان فـى النقد والأدب ـ بيـروت: دار الكتــاب اللبنانى، 1991 الرسائل ـ عبد اللطيف، جواحى. القضايا النقديةفى كتاب الايوان واثرها فى الحركة النقدية الحديثة. 2014 